\title{
Influence of NMDA and GABA synaptic dysfunction on the evoked gamma oscillations in a computational model of schizophrenia
}

\author{
Rokas Jackevičius ${ }^{1}$, \\ Bruce P. Graham², \\ Aušra Saudargiene் $\dot{1}^{1,3}$ \\ ${ }^{1}$ Department of Informatics, \\ Vytautas Magnus University, \\ Vileikos 8, 44404 Kaunas, Lithuania \\ ${ }^{2}$ Division of Computing \\ Science and Mathematics, \\ Faculty of Natural Sciences, \\ University of Stirling, \\ Stirling FK9 4LA, Scotland, \\ United Kingdom \\ ${ }^{3}$ Neuroscience Institute, \\ Lithuanian University \\ of Health Sciences, \\ Eiveniu 4, 50161 Kaunas, \\ Lithuania
}

Background. Schizophrenia is a psychiatric disorder which is characterized by delusions and hallucinations, and affects thoughts, behaviour and emotions. Major neuronal degeneration is not observed in schizophrenic patients, but abnormalities in cortical circuits are present. These abnormalities are reflected in impaired EEG gamma frequency $(30-80 \mathrm{~Hz})$, being crucial for many processes including sensation, perception, working memory, and attention. NMDA and GABA synaptic dysfunction is proposed as one of the possible mechanisms underlying the gamma oscillatory deficits in schizophrenia.

Materials and Methods. We used a computational modeling approach to investigate the joint influence of NMDA and GABA synaptic dysfunction on gamma oscillations in cortex. We employed a computational model of a spiking neural network composed of 800 pyramidal neurons, 150 regular-spiking interneurons, and 50 fast-spiking interneurons. All cells were randomly interconnected. Network neurons received independent Poisson noise input at $4 \mathrm{~Hz}$ and $40 \mathrm{~Hz}$ drive excitatory stimulation. Fast-spiking interneuron GABA receptor-gated channel time constant was increased and NMDA receptor-gated channel synaptic conductance was decreased to represent synaptic dysfunction in schizophrenia.

Results. Reducing NMDA conductance enhanced gamma power, and increasing decay time constant of GABA receptorgated channel attenuated gamma generation in a network. The effect of synaptic GABA alteration was more profound.

Conclusions. NMDA and GABA synaptic dysfunction leads to the impaired gamma frequency oscillations in a spiking neural network of cortex. Computational modeling approach is a powerful tool to understand complex non-linear dynamical systems and intrinsic mechanisms of neuronal network activity in healthy and diseased brain.

Keywords: schizophrenia, spiking-neural network, gamma oscillations, NMDA receptor, GABA receptor

\footnotetext{
* Corresponding author: E-mail: ausra.saudargiene@vdu.lt
} 


\section{INTRODUCTION}

Schizophrenia is a disabling chronic mental illness that affects one percent of the general population. Schizophrenic patients suffer from hallucinations, delusions, thought and movement disorders, apathy, neurocognitive deficits such as poor attention, distractability, and impaired working-memory (Mueser, McGurk, 2004). Morphological abnormality in the temporal cortex, the limbic and frontal cortex are commonly observed in schizophrenia (Lewis et al., 2005; Iritani, 2013). Impaired cortical network processing is reflected in altered oscillatory gamma frequency $(30-80 \mathrm{~Hz})$ response during sensory stimulation and spontaneous neuronal activity (Gallinat et al., 2004; Uhlhaasand Singer, 2013). For example, physiological experiments show that altered gamma rhythm response in schizophrenic patients is most evident when given periodic click train stimuli at $20 \mathrm{~Hz}$ and $40 \mathrm{~Hz}$ : the oscillation power is increased at $20 \mathrm{~Hz}$ and decreased at $40 \mathrm{~Hz}$ (Vierling-Claassen et al., 2008; Griskova-Bulanova et al., 2012).

$\mathrm{N}$-methyl-D-aspartate (NMDA) receptor and $\gamma$-aminobutyric (GABA) acid receptor dysfunction of cortical networks, reduced connectivity, and deficient neuromodulation are proposed as the possible mechanisms underlying the gamma oscillatory deficits in schizophrenia. The NMDA receptor hypofunction model of schizophrenia was inspired by the observation that NMDA agonists induce transient symptoms of psychosis and hallucinations (e.g., Olney et al., 1999; Coyle, 2012; Cohen et al., 2017). The NMDA receptors are also critical for the development and function of cortical GABAergic interneurons that are responsible for recurrent inhibition to the pyramidal neurons and play an important role in gamma frequency generation (Gonzalez-Burgos, Lewis, 2012). In addition, post mortem studies of schizophrenic patients showed that GABAergic interneurons have altered properties, captured by the extended synaptic decay time constant (Lewis et al., 2005; Vierling-Claassen et al., 2008).

Theoretical models of prefrontal cortex networks have been developed to understand the symptoms and intrinsic neuronal mechanisms of schizophrenia (review Rolls et al., 2008; Gonzalez-Burgos et al., 2005; VierlingClaassen et al., 2008; Spencer, 2009; Spencer, 2009; Kirli et al., 2014; Anticevic et al., 2015; Jadi et al., 2016; Metzner et al., 2016). In particular, modeling of impairment of evoked gamma oscillations in the auditory cortex received considerable attention: Vierling-Claassen et al. (2008) analysed the effect of GABA deficits; Kirli et al. (2014) evaluated the effect of NMDA deficits; Metzner et al. (2016) included GABA hypofunction and impaired connectivity. Spencer (2009) addressed the influence of reduced cortical connectivity and NMDA synaptic hypofunction in a resting state.

We use a computational model of auditory cortex to investigate the joint influence of NMDA and GABA synaptic dysfunction on the gamma oscillations in a resting state and in sensory stimulation conditions.

\section{MATERIALS AND METHODS}

A model of a spiking neural network was composed of 800 pyramidal neurons (PCs), 150 regular-spiking interneurons (RSIs) and 50 fast-spiking interneurons (FSIs) (Spencer et al., 2009). All neurons were randomly interconnected and received excitatory background inputs and sensory drive stimuli (Fig. 1). All cells had excitatory NMDA and $\alpha$-amino3-hydroxy-5-methyl-4-isoxazolepropionic (AMPA) acid synapses and inhibitory GABA synapses. Leaky-integrated and fire model was used to describe PCs, RSIs and FSIs dynamics. Membrane potential of PCs, RSIs and FSIs was expressed as:

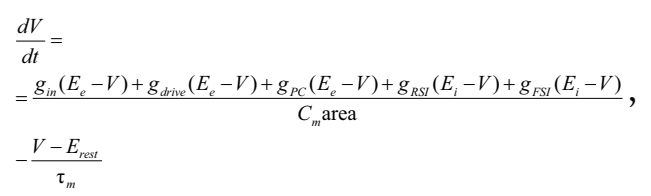

where $V$ is membrane potential, $g_{\text {in }}$ is synaptic conductance of the AMPA synapse receiving independent noise input, $g_{\text {drive }}$ is synaptic conductance of the AMPA synapse stimulated by sensory drive stimulus, $g_{P C}$ is synaptic conductance 


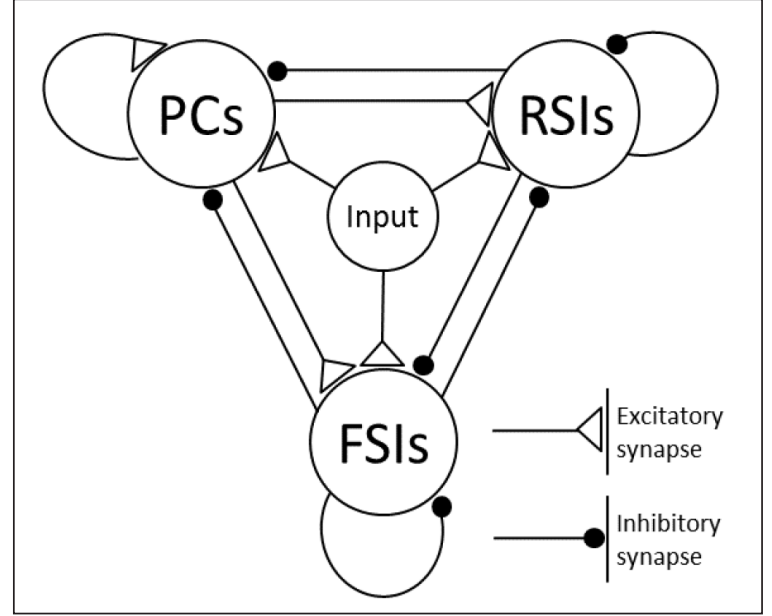

of AMPA synapse receiving input from pyramidal cells, $g_{R S I}$ is synaptic conductance of the GABA synapse receiving input from regular spiking interneurons, $g_{F S I}$ is synaptic conductance of the GABA synapse receiving input from fast spiking interneurons, $E_{e}$ and $E_{i}$ are reversal potentials of excitatory and inhibitory synapses, respectively, $E_{\text {rest }}$ is resting potential, $\tau_{m}$ is the membrane time constant, $C_{m}$ is membrane capacitance, area is the membrane area. Parameter values are presented in Table 1.

AMPA and GABA synaptic conductances are modeled as a double exponential function:

$g_{\text {syn }}=\bar{g}_{s y n} \frac{\tau_{\text {fall }} \tau_{\text {rise }}}{\tau_{\text {fall }}-\tau_{\text {rise }}}\left(e^{-\left(t-t_{\text {pre }}\right) / \tau_{\text {fall }}}-e^{-\left(t t_{\text {pre }}\right) / \tau_{\text {rise }}}\right)$,

where $\tau_{\text {rise }}$ is the rising time constant, $\tau_{\text {fall }}$ is the decay time constant, $\bar{g}_{s y n}$ is a peak synaptic conductance, $t_{\text {pre }}$ is the time of the synapse activation.

The NMDA receptor mediated synaptic response is expressed:

$$
g_{\text {syn }}=\bar{g}_{\text {syn }} \frac{\tau_{\text {fall }} \tau_{\text {rise }}}{\tau_{\text {fall }}-\tau_{\text {rise }}} \frac{e^{-\left(t-t_{\text {pre }}\right) / \tau_{\text {fall }}}-e^{-\left(t-t_{\text {pre }}\right) / \tau_{\text {rise }}}}{1+\mu\left[M g^{2+}\right] e^{-\gamma V}},
$$

where $\tau_{\text {ise }}$ is the rising time constant, $\tau_{\text {fall }}$ is the decay time constant, $\bar{g}_{s y n}$ is a peak synaptic conductance, $t_{\text {pre }}$ is the time of the synapse activation, $\left[\mathrm{Mg}^{2+}\right]$ is extracellular $\mathrm{Mg}$ concentration, $\mu$ and $\gamma$ are the parameters describing the influence of $\mathrm{Mg}$ concentration and membrane potential. Time constants, peak synaptic conductances, reversal potentials, $\mu$ and $\gamma$ parameters are presented in Table 1. Probabilities and peak
Fig. 1. Schematic diagram of the model of a cortical neural network. All pyramidal cells (PCs), regular spiking interneurons (RSIs), and fast spiking interneurons (FSIs) are randomly interconnected and receive Poisson noise input at $4 \mathrm{~Hz}$ and sensory drive input at $40 \mathrm{~Hz}$. Excitatory synapses include NMDA and AMPA receptor-gated channels, inhibitory synapses - GABA receptor-gated channels

synaptic conductances of each connection type between PCs, FSIs, RSIs are given in Table 2.

The background activity in the cortex is represented by an independent Poisson noise input to the network neurons at $4 \mathrm{~Hz}$. Sensory drive stimulus is modeled as excitatory input to the network neurons at $40 \mathrm{~Hz}$. Peak synaptic conductances for a resting state have been estimated using a genetic algorithm and are presented in Table 1.

The synaptic dysfunction in the schizophrenic state is modeled by altering synaptic properties of FSIs: GABA receptor-gated channel decay time constant is increased from $5 \mathrm{~ms}$ to $15 \mathrm{~ms}$, and NMDA receptor-gated channel synaptic conductance is decreased from $100 \%$ to $10 \%$.

To characterize network activity, power spectrum of the average membrane potential for each cell population was computed with a Fast Fourier Transform. Frequency resolution was chosen at $2 \mathrm{~ms}$.

The network was simulated for $1000 \mathrm{~ms}$. The model was implemented in the Brian Spiking Neural Simulator environment (Goodman DF, Brette, 2009; Stimber et al., 2014). Data analysis was performed in Matlab, The MathWorks, Inc.

\section{RESULTS}

Activity of the network in a resting state is shown in Fig. 2. Raster plot of 800 PCs, 150 RSIs, and 50 FSIs indicated that the network was synchronized after approximately $100 \mathrm{~ms}$ after the simulation onset in response to the background Poisson noise input at $4 \mathrm{~Hz}$ (Fig. 2A). 
Table 1. Parameters of the pyramidal cells (PCs), regular spiking interneurons (RSIs), fast spiking interneurons (FSIs), AMPA, NMDA, GABA synapses

\begin{tabular}{|c|c|}
\hline \multicolumn{2}{|l|}{ Network size } \\
\hline PCs (pyramidal cells) & 800 \\
\hline RSIs (regular-spiking interneurons) & 150 \\
\hline FSIs (fast-spiking interneurons) & 50 \\
\hline \multicolumn{2}{|l|}{ Cells } \\
\hline Firing threshold & $-52 \mathrm{mV}$ \\
\hline After-spike reset potential & $-59 \mathrm{mV}$ \\
\hline Resting potential $E_{\text {rest }}$ & $-70 \mathrm{mV}$ \\
\hline Spike transmission time & $2 \mathrm{~ms}$ \\
\hline PCs and RSIs membrane time constant $\tau_{m}$ & $20 \mathrm{~ms}$ \\
\hline FSIs membrane time constant $\tau_{m}$ & $10 \mathrm{~ms}$ \\
\hline Refractory time period constant & $2 \mathrm{~ms}$ \\
\hline Membrane capacitance $C_{m}$ & $1.0 \mu \mathrm{F} / \mathrm{cm}^{2}$ \\
\hline Membrane area area & $400 \mu \mathrm{m}^{2}$ \\
\hline \multicolumn{2}{|l|}{ Synapses } \\
\hline Reversal potential of excitatory synapse $E_{e}$ & $0 \mathrm{mV}$ \\
\hline Reversal potential of inhibitory synapse $E_{i}$ & $-70 \mathrm{mV}$ \\
\hline AMPA rise and decay time constants $\tau_{\text {rise, }} \tau_{\text {decay }}$ & $0.5 \mathrm{~ms}, 2 \mathrm{~ms}$ \\
\hline NMDA rise and decay time constant $\tau_{\text {rise, }} \tau_{\text {decay }}$ & $2 \mathrm{~ms}, 100 \mathrm{~ms}$ \\
\hline GABA rise and decay time constat $\tau_{\text {rise, }} \tau_{\text {decay }}$ & $0.5 \mathrm{~ms}, 5 \mathrm{~ms}$ \\
\hline NMDA/AMPA receptor conductance strength ratio for PCs & 0.45 \\
\hline NMDA/AMPA receptor conductance strength ratio for RSIs and FSIs & 0.1 \\
\hline$\left[\mathrm{Mg}^{2+}\right] \mathrm{Mg}^{2+}$ concentration & $1 \mathrm{mM}$ \\
\hline$\mu\left(\mathrm{Mg}^{2+}\right.$ concentration constant $)$ & $0.33 / \mathrm{mM}$ \\
\hline$\gamma$ constant & $0.062 / \mathrm{mV}$ \\
\hline \multicolumn{2}{|c|}{ Synaptic conductances (noise stimuli and sensory drive) } \\
\hline Excitatory input to PCs & $5.2 \mathrm{nS}, 52 \mathrm{nS}$ \\
\hline Excitatory input to RSIs & $1.1 \mathrm{nS}, 11 \mathrm{nS}$ \\
\hline Excitatory input to FSIs & $4.0 \mathrm{nS}, 40 \mathrm{nS}$ \\
\hline
\end{tabular}

Table 2. Probability and relative weights of PCs, FSIs, RSIs connections. Each relative weight was scaled by a factor of $8.25 \mathrm{nS}$ to obtain $\bar{g}_{s y n}$ (Spencer, 2009)

\begin{tabular}{cccccc|c|c|c|c|c}
\hline & PC-PC & PC-RSI & PC-FSI & RSI-PC & RSI-RSI & RSI-FSI & FSI-PC & FSI-RSI & FSI-FSI \\
\hline Probability & 0.1 & 0.4 & 0.4 & 0.5 & 0.15 & 0.5 & 0.5 & 0.35 & 0.6 \\
\hline $\begin{array}{c}\text { Relative } \\
\text { weight }\end{array}$ & 1.0 & 0.8 & 1.9 & 0.8 & 0.8 & 0.8 & 1.9 & 1.0 & 1.0 \\
\hline
\end{tabular}

The membrane potential of individual neurons and averaged across PCs, RSIs, FSIs populations is presented in Fig. 2B, C. The oscillation power, computed from the average membrane potential for each cell group, had a peak at $40 \mathrm{~Hz}$ for PCs, RSIs and FSIs (Fig. 3A). 


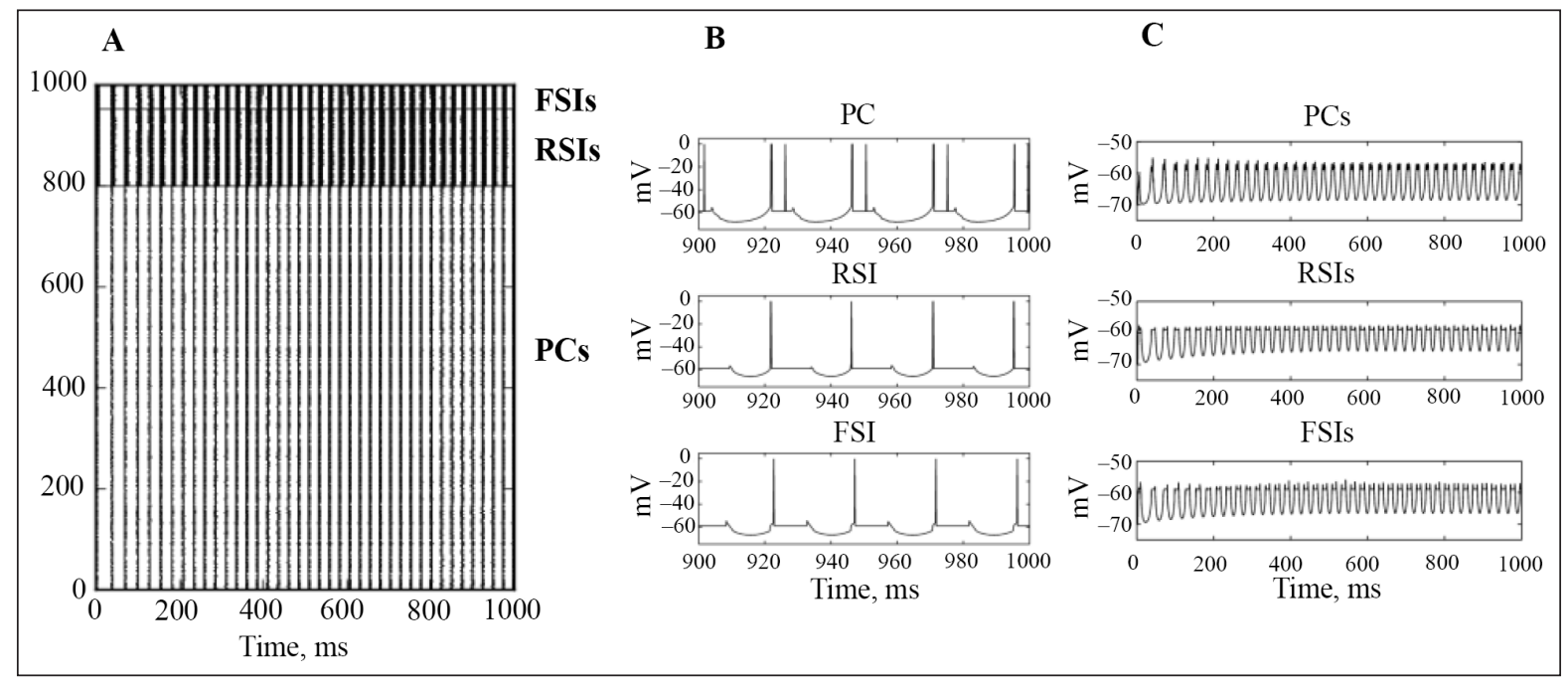

Fig. 2. Network activity in a resting state. (A) Raster plot of pyramidal cells (PCs, no. 1-800), regular spiking interneurons (RSIs, no. 801-950) and fast spiking interneurons (FSIs, no. 950-1000). (B) Membrane potential of PC, RSI, FSI. (C) Averaged membrane potential of PCs, RSIs, FSIs populations

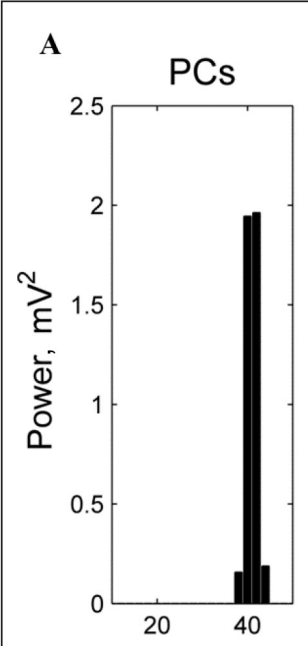

Frequency, $\mathrm{Hz}$

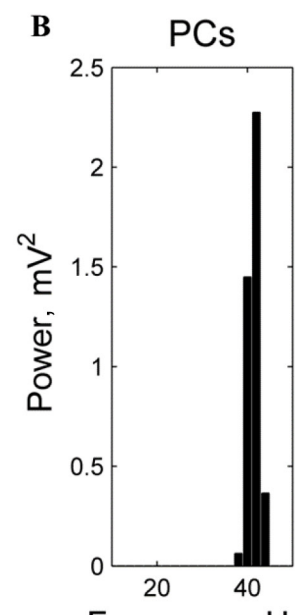

Frequency, $\mathrm{Hz}$
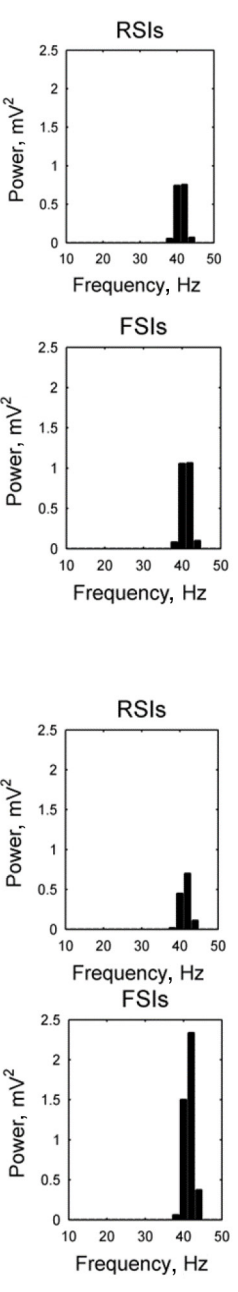

C

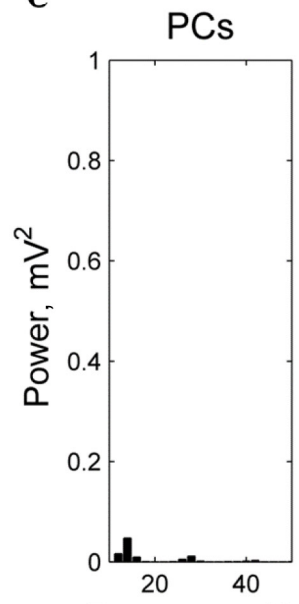

Frequency, $\mathrm{Hz}$
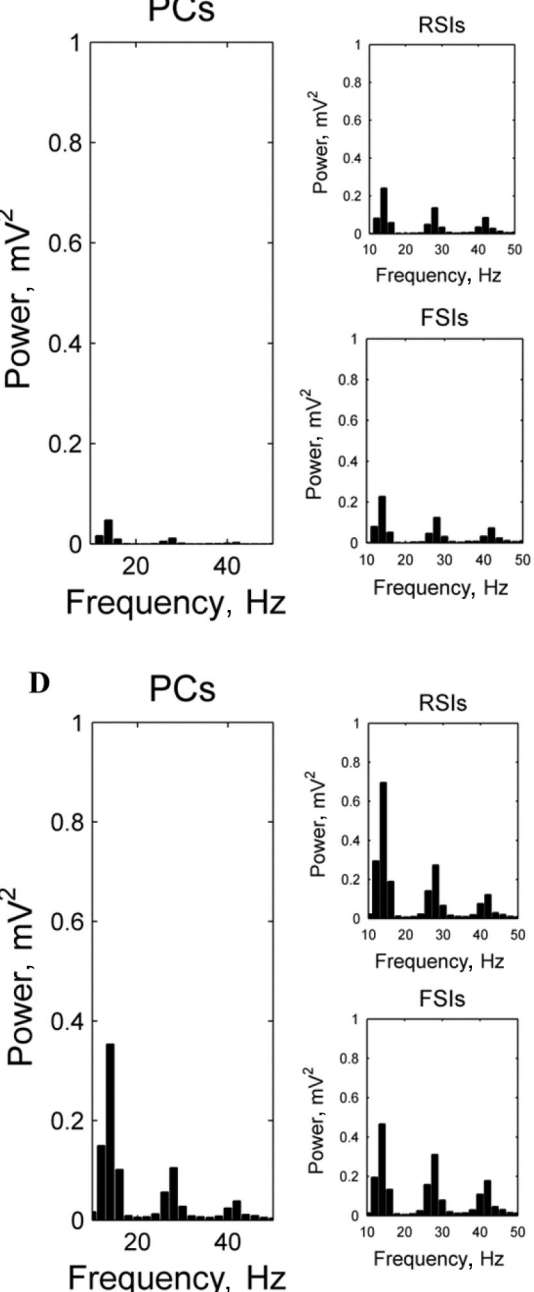

Fig. 3. Power spectral density of pyramidal cells (PCs), regular-spiking interneurons (RSIs), and fast-spiking interneurons (FSIs) in a resting state. (A, B) GABA receptorgated channel decay time constant is 5 ms. (C, D) GABA receptor-gated channel decay time constant is $15 \mathrm{~ms}$. (A, C) NMDA synaptic weight is $100 \%$. (B, D) NMDA synaptic weight is $10 \%$ 
Schizophrenic condition was modeled by altering NMDA and GABA synaptic properties of FSIs: synaptic conductance of NMDA receptor-gated channels was decreased up to $10 \%$ of its initial value (Fig. 3B, D), and GABA receptor-gated channel decay time constant was increased from $5 \mathrm{~ms}$ up to $15 \mathrm{~ms}$ (Fig. 3C, D).

In a resting state, weak NMDA synapses onto FSIs decreased oscillation power at $40 \mathrm{~Hz}$ in FSIs (from $1.1 \mathrm{mV}^{2}$ to $2.4 \mathrm{mV}^{2}$ ) and increasd oscillation power at $40 \mathrm{~Hz}$ in PCs (from $1.9 \mathrm{mV}^{2}$ to $2.35 \mathrm{mV}^{2}$ ), when GABA functioned normally (Fig. 3A, B). Prolonged decay time constant of
GABA receptor-gated channels led to the abolished gamma oscillations in PCs, FSIs and RSIs (Fig. 3C), when NMDA was unaffected. Deficits of both NMDA and GABA synapses increased oscillation power at $40 \mathrm{~Hz}$ in all cell populations (Fig. 3D), however, only slightly (up to $0.03 \mathrm{mV}^{2}$ in PCs and $0.16 \mathrm{mV}^{2}$ in FSIs), and introduced oscillations at lower frequencies $(10-30 \mathrm{~Hz})$.

$40 \mathrm{~Hz}$-drive stimulus increased oscillation power of PCs (up to $2.4 \mathrm{mV}^{2}$ ) and FSIs (up to $1.2 \mathrm{mV}^{2}$ ) at $40 \mathrm{~Hz}$ in a so-called healthy neural network (Fig. 4A). The raster plot of the network activity illustrates population syn-

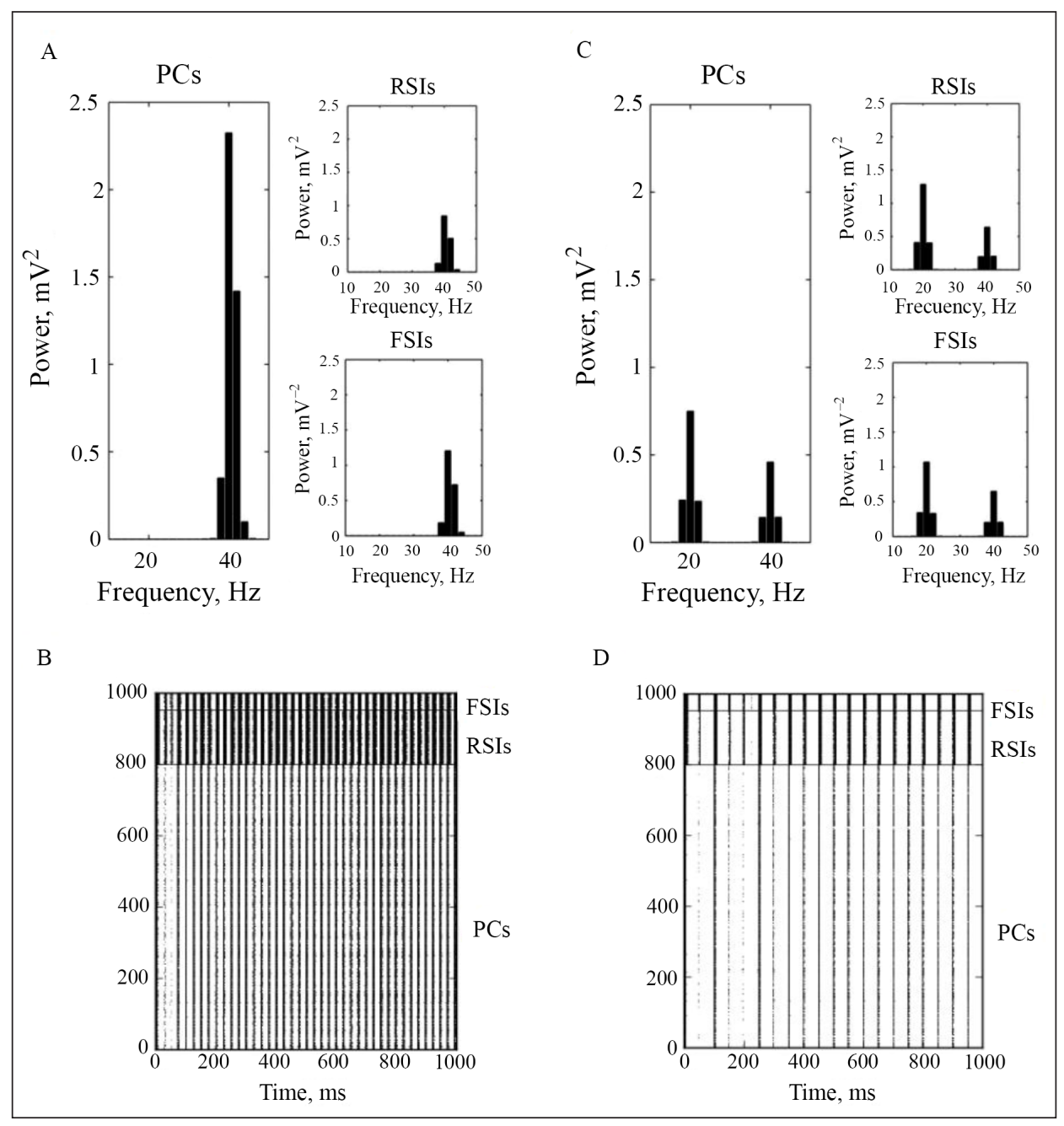

Fig. 4. Power spectral density $(A, C)$ and raster plots $(C, D)$ of pyramidal cells (PCs, no. 1-800), regular-spiking interneurons (RSIs, no. 801-950) and fast-spiking interneurons (FSIs, no. 950-1000) for $40 \mathrm{~Hz}$ drive case. NMDA synaptic weight is $100 \%$. $(\mathrm{A}, \mathrm{B}) \mathrm{GABA}$ receptor-gated channel decay time constant is $5 \mathrm{~ms}$. (C, D) GABA receptor-gated channel decay time constant is $15 \mathrm{~ms}$ 
chronization approximately after $75 \mathrm{~ms}$ after the simulation onset and rhythm generation at $40 \mathrm{~Hz}$ (Fig. 4B). Increased decay time constant of GABA receptor-gated channels onto FSIs diminished the oscillation power at $40 \mathrm{~Hz}$ $\left(0.4 \mathrm{mV}^{2}\right)$ and enhanced at $20 \mathrm{~Hz}\left(0.75 \mathrm{mV}^{2}\right)$ in PCs; similar effects were observed in FSIs and RSIs activity. Thus, $20 \mathrm{~Hz}$ oscillations became dominant in all three cell populations (Fig. 4B).

NMDA deficits had only a mild effect on network activity in $40 \mathrm{~Hz}$-drive conditions: PCs oscillation power slightly decreased for normal FSIs GABA synapse (Fig. 5A), and was not affected if GABA decay time constant was prolonged to $15 \mathrm{~ms}$ (Fig. 5B).

\section{DISCUSSION}

Synaptic dysfunction in schizophrenia was modeled by reducing NMDA synaptic conductance and increasing GABA decay time constant on FSIs of a cortical network model. The effect of synaptic GABA impairment was more profound in both conditions.
In a resting state, impaired NMDA synapses onto FSIs increase the oscillation power at $40 \mathrm{~Hz}$ in PCs as noise inputs provided weaker excitation for FSIs, and PCs were less inhibited. Similar observations on the influence of NMDA synaptic hypofunction in a resting state were reported by Spencer (2009). Prolonged decay time constant of GABA channels impairs network activity as FSIs-provided GABA inhibition of PCs and RSIs becomes more effective. Weak NMDA synapses onto FSIs enhance network oscillations, when GABA synapses are affected by illness. In $40 \mathrm{~Hz}$-drive stimulation case NMDA dysfunction effect is mild and does not influence network rhythm substantially. Kirli et al. (2014) found that varying NMDA conductance led to an inverted $U$ relation with network gamma oscillation. In our study NMDA influence is relatively small as inputs are strong and overpower NMDA dysfunction. GABA impairment decreases oscillation power at $40 \mathrm{~Hz}$ and increases at $20 \mathrm{~Hz}$ in PCs, FSIs and RSIs, as in the computational modeling study by Vierling-Claassen et al. (2008).

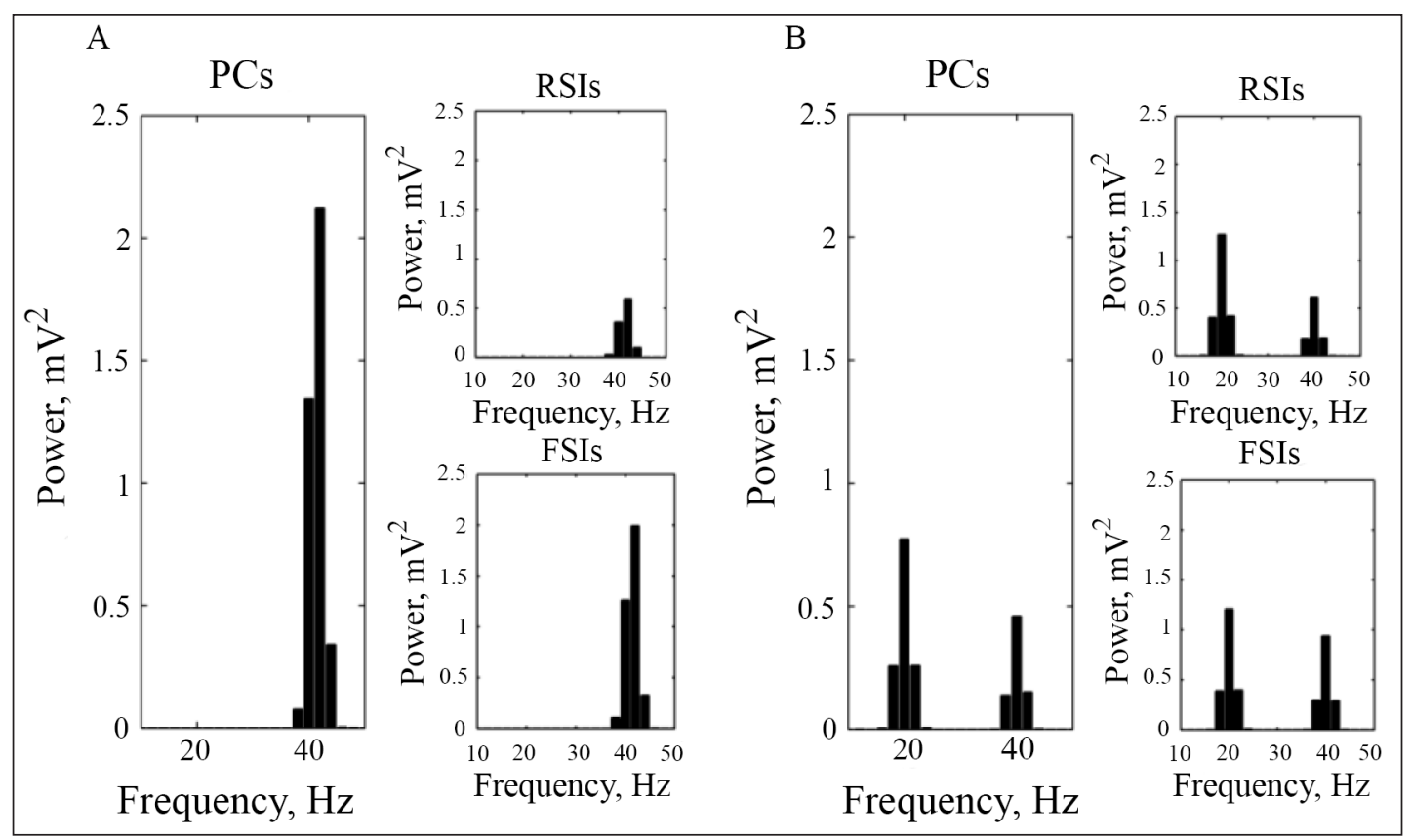

Fig. 5. Power spectral density of pyramidal cells (PCs), regular spiking interneurons (RSIs) and fast spiking interneurons (FSIs) for $40 \mathrm{~Hz}$ drive case. NMDA synaptic weight is $10 \%$. (A) GABA receptor-gated channel decay time constant is $5 \mathrm{~ms}$. (B) GABA receptor-gated channel decay time constant is $15 \mathrm{~ms}$ 
Influence of NMDA deficit is not evident if GABA is impaired.

\section{CONCLUSIONS}

NMDA and GABA synaptic dysfunction leads to the altered gamma frequency oscillations in a spiking neural network of cortex in a resting state and in $40 \mathrm{~Hz}$-drive case. Our simulation study shows that effect of synaptic GABA impairment is more profound in both conditions.

One of the recent trends in neuroscience is to develop computational models of psychiatric and neurological disorders and integrate the available knowledge at the molecular, cellular and system-levels (Friston et al., 2014; Adams et al., 2016; Huys et al., 2016; Raymond et al., 2017). This newly emergent field of computational psychiatry gives a new perspective on mental illness, serves as a bridge from neuroscience to clinical applications and advances understanding, prediction and treatment of psychiatric disorders. Computational modeling approach provides a powerful tool to study complex interactions, time courses and dynamics of multiple mechanisms underlying neuronal network activity in health and disease.

Received 17 March 2016

Accepted 9 June 2017

\section{References}

1. Adams RA, Huys QJM, Roiser JP. Computational psychiatry: towards a mathematically informed understanding of mental illness. J Neurol Neurosurg Psychiatry. 2016; 87(1): 53-63.

2. Anticevic A, Murray JD, Barch DM. Bridging Levels of Understanding in Schizophrenia Through Computational Modeling. Clin Psychol Sci. 2015; 3(3): 33-459.

3. Cohen SM, Tsien RW, Goff DC, Halassa MM. The impact of NMDA receptor hypofunction on GABAergic neurons in the pathophysiology of schizophrenia. Schizophrenia Research. 2015; 167(1-3): 98-107.
4. Coyle T. NMDA receptor and schizophrenia: a brief history. Schizophr Bull. 2012 Sep; 38(5): 920-6.

5. Friston KJ, Stephan KE, Montague R, Dolan RJ. Computational psychiatry: the brain as a phantastic organ. Lancet Psychiatry. 2014; 1(2): 148-58.

6. Gallinat J, Winterer G, Herrmann CS, Senkowski D. Reduced oscillatory gamma-band responses in unmedicated schizophrenic patients indicate impaired frontal network processing. Clin. Neurophysiol. 2004; 115: 1863-74.

7. Goodman DF, Brette R. The Brian simulator. Front Neurosci. 2009 doi:10.3389/neuro.01.026.2009.

8. Gonzalez-Burgos G, Lewis DA. GABA neurons and the mechanisms of network oscillations: implications for understanding cortical dysfunction in schizophrenia. Schizophr Bull. 2008; 34(5): 944-61.

9. Gonzalez-Burgos G, Lewis DA. NMDA receptor hypofunction, parvalbumin-positive neurons, and cortical gamma oscillations in schizophrenia. Schizophr Bull. 2012; 38(5): 950-7.

10. Griskova-Bulanova I, Dapsys K, Maciulis V, Arnfred SM. Closed eyes condition increases auditory brain responses in schizophrenia. Psychiatry Res. 2012; 211(2): 183-5.

11. Jadi MP, Behrens MM, Sejnowski TJ. Abnormal Gamma Oscillations in N-Methyl-DAspartate Receptor Hypofunction Models of Schizophrenia. Biol. Psychiatry. 2016; 79(9): 716-26.

12. Iritani S. What happens in the brain of schizophrenia patients? An investigation from the viewpoint of neuropathology. Nagoya J Med Sci. 2013; 75: 11-28.

13. Huys QJM, Maia TV, Frank MJF. Computational psychiatry as a bridge from neuroscience to clinical applications. Nature Neuroscience. 2016; 19: 404-13.

14. Kirli KK, Ermentrout GB, Cho RY. Computational study of NMDA conductance and cortical oscillations in schizophrenia. Front Comput Neurosci. 2014; 8: 133. 
15. Lewis DA, Hashimoto T, Volk DW. Corical inhibitory neurons and schizophrenia. Nat. Rev. Neurosci. 2005; 6: 312-24.

16. Metzner C, Schweikard A, Zurowski B. Multifactorial Modeling of Impairment of Evoked Gamma Range Oscillations in Schizophrenia. Front Comput Neurosci. 2016 Aug 26; 10: 89.

17. Myme CI, Sugino K, Turrigiano GG, Nelson SB. The NMDA-to-AMPA ratio at synapses onto layer $2 / 3$ pyramidal neurons is conserved across prefrontal and visual cortices. J. Neurophysiol. 2003; 90(2): 771-9.

18. Mueser KT, McGurk SR. Schizophrenia. Lancet. 2004; 363: 2063-72.

19. Olney JW, Newcomer JW, Farber NB. NMDA receptor hypofunction model of schizophrenia. J Psychiatr Res. 1999; 33: 523-33.

20. Raymond JG, Steele JD, Seriès P. Modeling Trait Anxiety: From Computational Processes to Personality. Frontiers in Psychiatry. 2017; 8: 1.

21. Rolls ET, Loh M, Deco G, Winterer G. Computational models of schizophrenia and dopamine modulation in the prefrontal cortex. Nat. Rev. Neurosci. 2008; 9: 696-709. 10.1038/ nrn2462

22. Spencer KM. The functional consequences of cortical circuit abnormalities on gamma oscillations in schizophrenia: insights from computational modeling. Front Hum Neurosci. 2009; 3: 33 .

23. Stimberg M, Goodman DFM, Benichoux V, Brette R. Equation-oriented specification of neural models for simulations. Frontiers Neuroinf. 2014; doi: 10.3389/fninf.2014.00006.

24. Vierling-Claassen D, Siekmeier P, Stufflebeam S, Kopell N. Modeling GABA alterations in schizophrenia: a link between impaired inhibition and altered gamma and beta range auditory entrainment. J. Neurophysiol. 2008; 99(5): 2656-71.

25. Uhlhaas PJ, Singer W. High-frequency oscillations and the neurobiology of schizophrenia. Dialogues Clin Neurosci. 2013; 15(3): 301-13.

\section{Rokas Jackevičius, Bruce P. Graham, Aušra Saudargienè}

\section{NMDA IR GABA SINAPSIŲ DISFUNKCIJOS POVEIKIS GAMA DAŽNIO OSCILIACIJOMS ŠIZOFRENIJOS LIGOS ATVEJU: KOMPIUTERI- NIS MODELIAVIMAS}

\section{Santrauka}

Šizofrenija - tai psichikos liga, pasireiškianti suvokimo, mąstymo bei elgesio ir emocijų pokyčiais. Šizofrenija sergančiųjų smegenyse neuronų nykimas nèra aptinkamas, tačiau smegenų žievèje pastebimi patologiniai signalų perdavimo pokyčiai, t. y. pakitęs EEG gama dažnis $(30-80 \mathrm{~Hz})$, kuris yra ypač svarbus tokiems procesams kaip pojūčiai, suvokimas, atmintis ir dèmesys. Pastaruoju metu manoma, kad NMDA ir GABA sinapsių disfunkcija yra vienas iš galimų priežastinių mechanizmų, sukeliančių gama ritmo sutrikimus sergant šizofrenija. Šiame darbe taikant kompiuterinio modeliavimo metodą siekiama ištirti NMDA ir GABA sinapsių disfunkcijos poveikị gama dažnio pokyčiams smegenų žievëje. Tyrimo metu nustatyta, kad mažesnis NMDA receptorių valdomų kanalų laidumas padidino gama svyravimų galią, o ilgesnè GABA receptorių valdomų kanalų gesimo laiko konstanta ją sumažino. GABA sinapsių savybių pokyčių itaka yra ryškesnè. NMDA ir GABA sinapsių disfunkcija lemia pakitusius gama dažnio svyravimus smegenų žieves neuronų tinkle. Kompiuterinio modeliavimo metodas yra galingas įrankis, leidžiantis tirti sudètingas netiesines dinamines sistemas, aprašančias vidinius neuroninio tinklo aktyvumą palaikančius mechanizmus sveikose ir pažeistose smegenyse.

Raktažodžiai: šizofrenija, veikimo potencialą generuojantis neuroninis tinklas, gama svyravimai, NMDA receptoriai, GABA receptoriai 